\title{
THE GEOLOGY AND MINERALOGY OF SOME KIMBERLITES IN THE MWADUI AREA
}

Gobba, J.M.

Williamson Diamonds Ltd., Mwadui Mine, Tanzania.

The Mwadui kimberlite-bearing area is located in the Tanzania Archean Craton (2.5 - $3.0 \mathrm{Ma})$. The craton contains the oldest rocks known in Tanzania namely greenstones (basic and acid metavolcanics, banded ironstones and metasediments) and granitoids. The majority of the kimberlites lie within the craton and the Mwadui area is one with the highest number of fertile kimberlites. Out of the 67 known kimberlites in the latter area, 25 are diamondiferous, and only 3 have been economically exploited for diamonds. Among the three economic kimberlites is the Mwadui kimberlite pipe covering an area of about 146 ha making it the largest kimberlite in the world. Since its discovery (1940) the Mwadui pipe has produced 3.4 tons of diamonds valued at US\$l200 million.

The Mwadui area kimberlites were emplaced into the granitoids and greenstones during the Early Tertiary times (40-53 Ma; Davis, 1977; Raber, 1978; Shee, 1981). A considerably older age of Mid-Proterozoic (1097 Ma) has been obtained for one kimberlite in the Bubiki area (Bristow, 1986).

A preferred structural trend of the kimberlites is NE-SW which coincides with the trend of dolerite dyke swarms of Upper Proterozoic age. The Mwadui pipe lies at the intersection of the NE-trending dolerite dykes and a NWstriking shear zone. Close to the pipe is a major NNE-trending lineament. A structural trend between $N$ and NNE appears to be associated with major kimberlitic intrusions e.g. Mwadui, Mhunze and Nyamigunga.

Macroscopic and microscopic study done recently has permitted in the mineralogical and textural classification of kimberlites in the Mwadui area. The mineralogical

classification follows Skinner and Clement (1979) and is based on the predominant macrocrysts whereas the textural classification (Clement and Skinner, 1979) gives the facies (crater, diatreme and hypabyssal).

The study of the geology of the Mwadui pipe has shown that all the facies of a true kimberlite are preserved namely crater, diatreme, and hypabyssal (Gobba, 1989). In the crater facies are found both epiclastic and pyroclastic kimberlitic sediments (tuffs, shales, mudstones). The crater facies rocks are overlain by superficial deposits (gravels, silcretes calcretes, and clays). Below the bedded crater facies rocks are the diatreme facies tuffisitic kimberlite breccias which are characterized by abundant unaltered xenoliths, discrete and fragmented autoliths of hypabyssal kimberlite and xenocrysts from from deeper crustal/mantle sources. True hypabyssal facies within the main pipe has not been exposed. However, there are kimberlite dykes to the $N$ and $S$ of the main 
pipe which show mineralogical and textural properties of hypabyssal kimberlite. The dyke to the north has a NE-SW orientation and is an altered serpentine-diopside kimberlite. The southern dyke has a SE trend and is an altered kimberlite containing serpentine and clay minerals.

A few other kimberlites show all the three facies (e.g. Mhunze and Nyamigunga) whilst most of the remaining are eroded to deeper levels removing some of the facies (mainly the crater facies).

Many Mwadui area kimberlitic intrusions are characterised by an absence of macrocrystal olivine and it is suggested that these could be related rocks here after called parakimberlites, transitional between kimberlites and other ultramafic rocks (Gobba and Saxby, 1982; Gobba and Edwards, 1983). The criteria used in this study to classify a rock as a para-kimberlite is the morphology of olivine grains and the presence of groundmass minerals such as nepheline or analcime (Shee, 1980). Some kimberlitoids have been found in Mwadui area e.g. $65 \mathrm{~K} 34 \mathrm{kimberlite} \mathrm{pipe.} \mathrm{In} \mathrm{this} \mathrm{intrusion} \mathrm{extensive}$ mineral alteration to serpentine, carbonates and clay minerals are common. Pseudomorphs of olivine and monticellite are found, spinels and apatite are ubiquitous. At Bubiki ( $48 \mathrm{~K} 5$ kimberlite pipe) olivines have unusual shapes and perovskites are unusually large. Overall the rock is considered to be a marginal kimberlite possibly transitional to an olivine melilite type rock association.

Some of the occurrences may represent aphanitic kimberlites and may have come about through filter pressing process. These however are not common and usually occur in specific geological settings such as dykes and sills. The fairly widespread occurrence with this texture is unusual for kimberlites. Several possibilities are given by wyatt (1983) who suggested that they could be of relevance if these rocks are kimberlites. Firstly, they could have unusual structural control which could account for the removal of coarse constituents. Alternatively the absence of macrocrysts could be an intrinsic feature of the Mwadui area as a whole. It is therefore interesting to speculate that since the Mwadui kimberlite is almost completely preserved, we may be observing, in the Mwadui area, the terminal features of kimberlitic episodes that may not normally be observed in other areas. However considering combined evidence to date it seems probable that these occurrences are related rocks rather than aphanitic kimberlites. In regard to this it would seem that the presence of Mwadui true kimberlite in a province with fairly numerous occurrences of kimberlite-related rocks is unusual.

\section{REFERENCES}

BRISTOW, J.W. (1986) Ion probe U-Pb peroviskite dating of the Bubiki kimberlite, Tanzania. Report on specimen CBE 5/25 Research School of Earth Sciences, Australian National University, Canberra.

CLEMENT, C.R. and SKINNER, E.M.W. (1979) A textural genetic classification of kimberlite rocks. Poster session abstracts, De Beers kimberlite symposium, Cambridge, U.K. 
DAVIS, C.I. (1977) The ages and uranium contents of zircons from kimberlites and associated rocks. Carnegie Institute, Washington, Yearbook 76, p. 631-654.

GOBBA, J.M. (1989) Kimberlite exploration in Tanzania. Journal of African Earth Sciences, 9, 3/4, 565-578.

GOBBA, J.M. and SAXBY, P.B. (1982) Report on prospecting Licence $1 / 81$ covering 104 square kilometers near Mhunze/Kishapu, Shinyanga Region. Unpublished Report Williamson Diamonds Limited.

GOBBA, J.M. and EDWARDS, C.B. (1983) Report on prospecting Licence $1 / 81$ covering 885 square kilometers near Mhunze/Kishapu area, Shinyanga Region. Unpublished Report, Williamson Diamonds Limited.

RABER, E. (1978) Zircons from diamond-bearing kimberlites. oxide reactions, fission track dating and mineral inclusions study. M.Sc. thesis, University of Massachussets.

SHEE, S.R. (1981) Dating of mineral and whole rock samples by $\mathrm{U}-\mathrm{Th}-\mathrm{Pb}$ method and application to kimberlites. Kimberly Petrographic Laboratory Report no.DBG/PI/8I-88 of $47 / 11 / 81$.

SHEE, S.R. (1980) The petrography of some Tanzanian kimberlites and para-kimberlites. Unpublished Report no. DBG/PI/80, Williamson Diamonds Limited.

SKINNER, E.M.W. and CLEMENT, C.R. (1979) Mineralogical classification of South African kimberlites. Proceedings of 2nd International Conference, l, 129-135.

WYATT, B.A. (1983) Petrography of assorted rock samples derived over aeromagnetic anomalies in the Mwadui area in Tanzania. Unpublished report no. AARI 475. WDS 1124 Williamson Diamonds Limited. 